\title{
Generic pronouns in the Wellington Corpus of Spoken New Zealand English
}

\author{
Janet Holmes
}

\section{Example 1}

Everyone should bring his own copy of the report to the meeting

In example 1, the writer scrupulously follows Lindley Murray's fifth rule of syntax which states that a pronoun must agree with its antecedent in gender and in number (Murray 148). The well-established use of they and their for this purpose, recorded from the early sixteenth century (Mühlhäusler and Harré 231), was rejected by eighteenth century prescriptive grammarians as ungrammatical, and the coordinate construction he or she was dismissed as too clumsy. He was the most popularly prescribed solution and so Everyone should bring his own copy was declared grammatical. The fact that this usage broke the prescriptive requirement for gender concord was resolved by the declaration that in such instances he includes she, a resolution which was enshrined in an 1850 British Act of Parliament, purportedly for reasons of economy ('to shorten the language used in Acts of Parliament') rather than grammaticality (Bodine 131-132, Henley 13). So-called generic he was thus bolstered by legislation as well as prescriptive grammarians. ${ }^{1}$

But usage has been changing. Generic he no longer holds the sway it once did, despite the best efforts of prescriptive grammarians. In the last decade of the twentieth century, we can reasonably label it a 'pseudogeneric'. Many recent studies report the steady decline of pseudo-generics such as he and man, especially in American English. Most studies examine the written usage of American college and university students as exemplified in essays or elicited samples (eg. Meyers 1990, 1993, Wheeless et al.). Cooper documents the decline of pseudo-generics in a 500,000 word written corpus consisting of American newspapers, magazines, periodicals and the Congressional Record, and a 75,000-word sample from the British The Times Literary Supplement over the period 1971- 
1979. Newman $(1992,1996)$ identifies the same pattern in the pronominal choices of speakers in a corpus of American TV interviews. Sunderland reports the decline of pseudo-generics in written British English over the last thirty years or so, and Pauwels discusses Australian usage in this area.

In New Zealand there has been very little research investigating pseudogenerics. Changes in attitudes and perceptions of the meaning of such usages have been described among Otago academics (Stewart, Verstraate and Fanslow), and New Zealand social psychologists have provided support for the claim that pseudo-generics elicit mainly male images (e. $g$. Wilson and $\mathrm{Ng}, \mathrm{Ng}$ ). But we have little evidence about whether New Zealanders follow the purists' grammatical prescriptions or instead adopt non-sexist usages. Moreover, as with studies of overseas varieties, the little research there is has focussed on written usage.

The results of research in this area to date paint a rather mixed picture. Vivienne Holt wrote to ten newspapers and a Christchurch columnist seeking views on non-sexist usages. She found that these influential gatekeepers of written usage held predominantly negative attitudes towards non-sexist terminology: most, for instance, explicitly banned person usages. On the other hand, Miriam Meyerhoff charted a decline in the use of pseudo-generics (including he and man) in five New Zealand newspapers between 1964 and 1984. Brenda Zanetti interviewed adults about their reactions to non-sexist generic they, and administered tests to intermediate students to elicit their written usage. She concluded that conservative grammatical norms still strongly influence written usage. A surprising number of her subjects selected generic he following words such as everybody (though this result may reflect her method which specifically drew attention to such forms). More recently I compared the use of pseudo-generic man in the press sections of the Wellington Corpus of Written New Zealand English (WCWNZE), the Australian Macquarie Corpus and the British LOB Corpus (Holmes). The results suggested that New Zealand was ahead of Australia in avoiding the use of pseudo-generic man.

Clearly there is room for further research in this area. Not only are the patterns in written usage still unclear, we do not yet have any information on the spontaneous choices of 'ordinary' New Zealanders in contexts where a generic is required, either in speech or in writing. 


\section{GENERIC PRONOUNS IN SPOKEN USAGE: FREQUENCIES}

Which pronouns do New Zealanders use after words like everyone and anybody? I provide here the results of a preliminary analysis of the use of generic pronouns in the Wellington Corpus of Spoken New Zealand English (WCSNZE).

The WCSNZE consists of one million words of New Zealand speech, of which half comprises face-to-face informal conversation, a quarter comprises informal dialogue such as phone conversations, radio talkback, and business transactions (shops, meetings etc), and a quarter comprises more formal speech (interviews, lectures, broadcast material etc). (See Appendix.) The analysis examines the occurrence in the Corpus of pronouns which follow non-specific referents such as anyone and everyone. ${ }^{2}$

The first step in the procedure was a manual inspection of an initial concordance of almost 7000 tokens to identify potential antecedents such as anyone, anybody, nobody, no-one, person, somebody, someone, whoever: i. e. cases where the speaker had no specific referent in mind. (This was not always easy to establish, even with extensive context.) In total, there were 272 occurrences in the WCSNZE of pronominal forms following such words. This seems a relatively small number in such a large corpus, indicating how difficult it is to study the distribution of grammatical patterns in naturally occurring speech; nevertheless, it is a reasonable sample for examining pronoun choices of this kind. Table 1 provides information on the distribution of these pronouns according to their grammatical function.

Table 1: Generic pronouns by grammatical category

\begin{tabular}{|l|l|l|l|l|l|}
\hline Pronoun: & Subj. & Obj. & Gen. & Refl. & Total \\
\hline \multirow{2}{*}{$\begin{array}{l}\text { they; them; their; } \\
\text { themselves/themselves }\end{array}$} & 108 & 50 & 53 & 5 & 216 \\
\hline & $(78.8 \%)$ & $(94.3 \%)$ & $(71.6 \%)$ & $(62.5 \%)$ & $(79.4 \%)$ \\
\hline \multirow{2}{*}{ he; him; his; himself } & 8 & 2 & 14 & 3 & 27 \\
\hline & $(5.8 \%)$ & $(3.8 \%)$ & $(18.9 \%)$ & $(37.5 \%)$ & $(9.9 \%)$ \\
\hline & & & & & \\
\hline you; you; your; yourself & 16 & 1 & 3 & & 20 \\
\cline { 2 - 7 } & $(11.7 \%)$ & $(1.9 \%)$ & $(4.1 \%)$ & & $(7.4 \%)$ \\
\hline & & & & & \\
\hline
\end{tabular}




\begin{tabular}{|l|l|l|l|l|l|}
\hline he/she; his/hers & $1(0.7 \%)$ & & $3(4.1 \%)$ & & $4(1.5 \%)$ \\
\hline & & & & & \\
\hline$I$ & $3(2.2 \%)$ & & & & $3(1.1 \%)$ \\
\hline her & & & & & \\
\hline & & & $1(1.3 \%)$ & & $1(0.4 \%)$ \\
\hline we & & & & & \\
\hline & $1(0.7 \%)$ & & & & $1(0.4 \%)$ \\
\hline Total & & & & & \\
\hline
\end{tabular}

Several points deserve comment. Firstly, it is clear that forms of they far outnumber all other generic pronouns, regardless of grammatical function.

\section{Example 2}

anybody whose superannuation is reduced because it's abated is still always better off than if they relied wholly on guaranteed retirement income

\section{Example 3}

but music's something that brings people together and I guess everybody's got their own style

In most contexts, it seems, New Zealanders spontaneously select the nonsexist pronoun they rather than the prescriptively 'correct' forms he or his in their spoken English.

Forms of the male pseudo-generic he are used in speech, though at $10 \%$ they are not very frequent at all. They tend to occur in genitive or reflexive roles.

\section{Example 4 (genitive)}

I think each individual got to make his own decision

\section{Example 5 (reflexive)}

[Referring back to a form such as "each individual "in example 3] that's a waste waste of himself too

These environments together account for only 30\% of the sample, but include $63 \%$ of the pseudo-generic male pronouns. But these instances are not randomly distributed: e.g. one of the three reflexive examples involves 
a quotation from a legal document, and another an idiomatic set phrase every man for himself. Another point of interest is the fact that the strategies of shifting to first person or second person pronouns are especially favoured in the subject roles.

\section{Example 6}

yeah so if anyone's got any other questions you want to discuss on that topic before we move on to the next

Possible reasons for these patterns are discussed in the next section.

\section{GENERIC PRONOUNS BY TEXT CATEGORY}

There are some interesting differences in the distribution of generic pronouns in the Corpus according to the contexts in which they occur. Using the nominative form as a label to cover all forms of a given pronoun, table 2 provides the distribution of generic pronouns in different styles of speech in the Corpus. (See Appendix for full interpretation of abbreviations.)

Table 2: Generic pronouns by text category

\begin{tabular}{|c|c|c|c|c|c|c|c|}
\hline & they... & he... & you... & he/she... & $I / w e$ & her & Total \\
\hline DGB & $31(78 \%)$ & $2(5 \%)$ & $5(13 \%)$ & $1(3 \%)$ & & $1(3 \%)$ & 40 \\
\hline DGI & $27(79 \%)$ & $6(18 \%)$ & $1(3 \%)$ & & & & 34 \\
\hline DGZ & $35(83 \%)$ & $1(2 \%)$ & $5(12 \%)$ & & $1(2 \%)$ & & 42 \\
\hline DPC & $85(87 \%)$ & $7(7 \%)$ & $6(6 \%)$ & & & & 98 \\
\hline DPF & $15(100 \%)$ & & & & & & 15 \\
\hline $\mathrm{DPH}$ & $5(83 \%)$ & & & & $1(17 \%)$ & & 6 \\
\hline DPP & $5(83 \%)$ & $1(17 \%)$ & & & & & 6 \\
\hline MSN & $1(100 \%)$ & & & & & & 1 \\
\hline MST & & $2(50 \%)$ & & & $2(50 \%)$ & & 4 \\
\hline MUC & $1(100 \%)$ & & & & & & 1 \\
\hline MUJ & $2(18 \%)$ & $6(55 \%)$ & $1(9 \%)$ & $2(18 \%)$ & & & 11 \\
\hline MUL & $6(60 \%)$ & $2(20 \%)$ & $1(10 \%)$ & $1(10 \%)$ & & & 10 \\
\hline MUS & $3(75 \%)$ & & $1(25 \%)$ & & & & 4 \\
\hline Total & $\begin{array}{l}216 \\
(79.4 \%)\end{array}$ & $\begin{array}{l}27 \\
(9.9 \%)\end{array}$ & $\begin{array}{l}20 \\
(7.4 \%)\end{array}$ & $\begin{array}{l}4 \\
(1.5 \%)\end{array}$ & $\begin{array}{l}4 \\
(1.5 \%)\end{array}$ & $\begin{array}{l}1 \\
(0.4 \%)\end{array}$ & 272 \\
\hline
\end{tabular}


A couple of patterns are worth commenting on. Not surprisingly, perhaps, instances in section MUJ, the judges' summations, differ strikingly from all other text types in strongly disfavouring generic they (18\%). On this measure, these judges are the most conservative users of spoken New Zealand English in the WCSNZE. They clearly favour pseudo-generic he (55\%), though it is heartening to a feminist to find instances of he/she (18\%) in their summations. Formality of context always exerts pressure towards more conservative spoken forms, but this data indicates just how formal the context now needs to be before speakers abandon generic they. The data from lectures and teachers' monologue (sections MUL, MUS), for instance, indicates a preference for generic they over more conservative pseudo-generics.

Another interesting point in relation to the distribution of forms by texttype is the fact that half of the occurrences of second-person reference shift occur in the radio talkback (DGB), and business transactions (DGZ) material. It seems possible that in such contexts there may be some special persuasive benefit to explicitly identifying the hearer with the generic: i. e. generic you may be favoured because of its appeal to the listener in a situation where this is especially advantageous to the speaker. In example 7 , for instance, the speaker is recounting an embarrassing experience. Use of you rather than generic he or even they makes the account more dramatic and direct and emphasises the point being made.

\section{Example 7}

it's embarrassing saying to a someone else at the table that you have to pay for yours

There are some other unusual distributional patterns, but most involve too few tokens to permit generalisation or even to justify speculation (e. g. the fact that there are no occurrences of they in broadcast monologue may reflect simply individual preference, given we are discussing only 4 tokens).

\section{CONCLUSION}

Clearly a great deal more research needs to be undertaken to describe sexist and non-sexist usages in current New Zealand English, and to document the decline of pseudo-generics in particular. This short paper has examined just one aspect of current spoken usage-the distribution of 
generic pronouns in the Wellington Corpus of Spoken New Zealand English.

Overall, the analysis suggests that they is the default pronominalisation, used in speech for $80 \%$ of non-specific referents such as anyone. Forms of he occur less than $10 \%$ of the time in such contexts. In current New Zealand speech, then, there is good evidence to suggest that pseudogeneric he has all but disappeared. Non-sexist norms have demonstrably displaced the grammatically prescribed sexist forms in speech. Comparison with the Wellington Written Corpus is an obvious next step.

\section{APPENDIX: CORPUS CODES AND COMPOSITION}

$\begin{array}{lll}\text { Dialogue } & & \% \\ \text { DGB } & \text { Radio talkback } & 8 \\ \text { DGI } & \text { Broadcast interviews } & 9 \\ \text { DGU } & \text { Parliamentary debate } & 2 \\ \text { DGZ } & \text { Business transactions and meetings } & 10 \\ \text { DPC } & \text { Casual face-to-face conversations } & 48 \\ \text { DPF } & \text { Telephone conversations } & 7 \\ \text { DPH } & \text { Oral history interviews } & 2 \\ \text { DPP } & \text { Social dialect interviews } & 3\end{array}$

$\begin{array}{lll}\text { Monologue } & \text { \% } \\ \text { MSN } & \text { Broadcast news } & 3 \\ \text { MST } & \text { Broadcast monologue } & 1 \\ \text { MSW } & \text { Broadcast weather } & 0.3 \\ \text { MUC } & \text { Sports commentary } & 2 \\ \text { MUJ } & \text { Judges' summation } & 0.4 \\ \text { MUL } & \text { University lectures } & 3 \\ \text { MUS } & \text { Teachers' monologue } & 1\end{array}$

\section{WORKS CITED}

Bodine, Ann. 'Androcentrism in prescriptive grammar: singular they, sexindefinite he and he or she.' Language in Society 4, 2 (1975): 129-46.

Cooper, Robert L. 'The avoidance of androcentric generics.' International Journal of the Sociology of Language 50 (1984): 5-20. 
Henley, Nancy M. 'This new species that seeks a new language: on sexism in language and language change.' Women and Language in Transition. Ed. Joyce Penfield. Albany: State University of New York Press, 1987. 3-27.

Holmes, Janet. 'Charpersons and goddesses: non-sexist usages in New Zealand English.' Te Reo 36 (1993): 99-113.

Holt, Vivienne. 'How New Zealand newspapers name people.' Occasional Papers in Language and Linguistics 1 (1988): 9-18.

Meyerhoff, Miriam. 'Language and sex: research in New Zealand.' Women and Language in Australian and New Zealand Society. Ed. Anne Pauwels. Sydney: Australian Professional Publications, 1987. 32-44.

Meyers, Miriam Watkins. 'Current generic pronoun usage.' American Speech 65, 3 (1990): 228-237.

Meyers, Miriam Watkins. 'Forms of they with singular noun phrase antecedents: evidence from current educated English usage.’ Word 44, 2 (1993): 181-192.

Muhlhausler, Peter and Rom Harré. Pronouns and People: the Linguistic Construction of Social and Personal Identity. Oxford: Basil Blackwell, 1990.

Murray, Lindley. English Grammar. [1795] Reprint. Menston: Scolar, 1968.

Newman, Michael. 'Pronominal disagreements: the stubborn problem of singular epicene antecedents.' Language in Society 21, 3 (1992): 447-475.

Newman, Michael. Epicene Pronouns: The Linguistics of a Prescriptive Problem. London: Garland Publishing, 1996.

Ng, S.H. 'Androcentric coding of man and his in memory by language users.' Journal of Experimental Social Psychology 26 (1990): 455-464.

Pauwels, Anne. Women Changing Language. London: Longman, 1998.

Sigley, Robert and Janet Holmes (forthcoming). An analysis of sexist usages in the Wellington Corpus of Spoken New Zealand English.

Stewart, Malcolm W., Cynthia D. Verstraate and Janet L. Fanslow. 'Sexist language and university academic staff: attitudes, awareness and recognition of sexist language.' New Zealand Journal of Educational Studies. 25, 2 (1990): 115-125.

Sunderland, Jane. 'The decline of man.' Journal of Pragmatics 16 (1991): 505522.

Wheeless, Virginia E., Cynthia Berryman-Fink, and Denise Serafini. 'The use of gender-specific pronouns in the 1980s.' Encoder 9 (1982): 35-36.

Wilson, E. and S.H. Ng. 'Sex bias in visual images evoked by generics: a New Zealand study.' Sex Roles 18 (1988): 159-169.

Zanetti, Brenda. 'Towards a non-sexist language: a preliminary survey and analysis of singular they use in New Zealand English.' New Zealand English Newsletter 5 (1991): 26-34. 


\section{ENDNOTES}

[1] I would like to express appreciation to Laurie Bauer who read a draft of this paper and to Robert Sigley who assissted with the analysis.

[2] Robert Sigley used a computer programme (OCP) to extract the figures used in this note. A fuller analysis will be provided in Sigley and Holmes.

Originally published in Kōtare 1, no. 1 (1998), pp. 32-40. 